\title{
Comments
}

\section{BUSINESS LICENSING: THE CITY-STATE CONFLICT IN CALIFORNIA}

The rapid growth of the California economy with the corresponding increase in business activity in market areas no longer definable by city boundaries has made business regulation an important concern of the state, cities, and businesses. Today, there are few commercial activities that are not to some extent subject to municipal or state control. This control most commonly takes the form of the enigmatic business license. The purpose of this Comment is to investigate the present function of the business license and to review recent developments in California case law relating to its use.

\section{GENERAL POWERS OF CALIFORNIA CITIES}

Califorma municipalities are classified as either charter or general law cities depending upon how they were organized. ${ }^{1}$ By organizing under the procedure outlined in the constitution, a cliarter city ${ }^{2}$ accepts a constitutional grant of limited liome rule freedom, ${ }^{3}$ which empowers it to enact all ordinances that relate to "municipal affairs," subject only to the restrictions and linitations found in

1 CAL. CoNsr. art. XI, $\$ 6$ directs the legislature to provide a method of incorporation for those cities electing not to adopt a freehold charter. "In 1883, the Legislature followed the inandate of Section 6 and adopted the Municipal Corporations Act providing statutory charters for six different classes of cities based on population (Stats. 1883, p. 93). In 1955 the Legislature dropped all numerical classifications and the Act presently provides for one class of city called a 'general law' city (Stats. 1955, Ch. 624). Thus, California cities are either chartered cities or general law cities. There are now 294 general law cities and 7o chartered cities." Keller, New Councilmen and the Law of Municipal Corporations in California, B-5 (1960) (unpublished advisory opinion by counsel for League of California Cities).

2 Prior to the ratification of California's constitution in 1879, charters were granted to cities by special state legislative enactments. Art. XI, $\S 8$, of the constitution provided a new chartering method whereby a city with a population of 3,500 or more can elect a board of "freeholders" to franie the city charter. Ratification at a special or general election by a majority of qualified voters within the city constitutes an adoption of the charter as franed by the freeholders. A city which follows this method is termed a "freehold charter city." Those cities which had been granted "special" charters prior to 1879 were not required to change to a "frechold" charter and there may still be a few such cities in the state. In this Cominent, "charter city" will refer only to the "freehold charter city."

3 City of Pasadena v. Charleville, 215 Cal. 384, 10 P.2d 745 (1932).

4 CAL. Consr. art. XI, $\$ 6$ provides that a charter city may enact "all laws and regulations in respect to municipal affairs, subject only to the restrictions and limitations provided in their several charters, and in respect to other matters they shall be subject to and controlled by general laws." The term "municipal affairs" generally relates to those matters affecting the imternal affairs of a city which are not of statewide concern. See Walnut Creek v. Silveira, $47 \mathrm{Cal} .2 \mathrm{~d}$ 804, 306 P.2d 453 (1957). The courts, however, appear to use this term in two different contexts. "Municipal affairs" may be used to denote those inatters consistent with the terms of the city charter, e.g., West Coast Advertising Co. v. San Francisco, 14 Cal. 2d 516, 95 P.2d 138 (1939), or it may refer to those areas where city enactments are deemed free from state legislative interference, e.g., Ex parte Braun, 141 Cal. 204, 74 Pac. 780 (1903). This discussion is concerned with the latter, narrower use. 
its charter. ${ }^{5}$ A general law city, on the other hand, is one organized pursuant to statutory instructions and consequently it does not have the same measure of self-rule. Its corporate powers are limited to those granted by the California legislature and are always subject to withdrawal by that body. ${ }^{\circ}$

When there is a conflict between a state law and either an ordinance of a general law city or a "nonmunicipal affair" ordinance of a charter city, the state law will control and the ordinance will be invalid. ${ }^{7}$ Such a conflict is deemed to exist where a city legislates in a field already occupied by the state. While it is often difficult to determine when state legislation is intended to be exclusive, it is clear that state law is supreme when the legislature has expressly declared that there shall be no local regulation. ${ }^{8}$ When there has been no expression of legislative intent, the courts will critically examine the statute to determine whether the state has intended to occupy the field to the exclusion of municipal action. ${ }^{2}$ If an intent to occupy can be found, the ordinance will be held invalid because of the "inevitable conflict of jurisdiction which would result from dual regulations covering the same ground." 10

II

\section{THE NATURE OF THE BUSINESS LICENSE AND THE AUTHORITY TO LICENSE}

A busmess license has been defined as a permit ${ }^{11}$ given by a governmental body to engage in a given activity $;^{12}$ it is a franchise to carry on an occupation subject to the licensee's compliance with specified conditions. ${ }^{13}$ Customarily, the payment of a fee is required before the privilege represented by the license will be

5 Abbott v. City of Los Angeles, 53 Cal. 2d 674, 3 Cal. Rptr. 158, 349 P.2d 974 (1960); In re Porterfield, 28 Cal. 2d 91, 168 P.2d 706 (1946); Pipoly v. Benson, 20 Cal. 2d 366, 125 P.2d 482 (1942); Biber Elec. Co. v. City of San Carlos, 181 A.C.A. 399, 5 Cal. Rptr. 261 (1960). If a charter city ordinance is within the sphere of "municipal affairs" it is conpletely free from state legislative interference. But if it encroaches upon an area of statewide concern or is of mixed concern to both city and state, a state general law, to the extent that there is a conflict, supersedes the charter city's action and controls the subject matter. Abbott v. City of Los Angeles, supre at 681-82, 3 Cal. Rptr. at 163, 349 P.2d at 979.

- City of San Mateo v. Railroad Comm'n, 9 Cal. 2d 1, 68 P.2d 713 (1937). A general law "city is limited in the exercise of its powers by the constitution and general laws. It has only the powers expressly conferred and such as are necessarily incident to those expressly granted or essential to the declared objects and purposes of the municipal corporation. Its powers are strictly construed and any fair, reasonable doubt concerning the exercise of a power is resolved against the corporation. ... [A]n ordinance adopted by a city organized under general law is subject to and controlled by general law." Hurst v. City of Burlingame, 207 Cal. 134, 138, 277 Pac. 308, 310 (1929).

7 CaI. Consr. art. XI, $\$ \S 6,11$; Cax. Gov't Code $\$ 37100$.

8 E.g., Biber Elec. Co. v. City of San Carlos, 181 A.C.A. 399, 5 Cal Rptr. 261 (1960).

${ }^{8}$ See Agnew v. City of Los Angeles, 51 Cal. 2d 1, 330 P.2d 385 (1958).

10 Pipoly v. Benson, 20 Cal. 2d 366, 371, 125 P.2d 482, 485 (1942) (dictum). If a jurisdictional conflict were allowed, a prosecution under a city ordinance would deprive the state of its criminal penalties because of the "double jeopardy" of the defendant. It is for this reason that a city regulation duphicating a regulation by the state will be held invalid. Thus, in Ex parte Stephen, 114 Cal. 278, 46 Pac. 86 (1896), a county penal ordinance enacted to enforce business hicense requirements was held void as in contravention of the general law of the state. "It undertakes to punish the same act-carrying on a business without having a hicense therefor-which is punishable under section 435 of the Penal Code [now Cax. Bus. \& Pror. Code \$ 16240]." $I d$. at 282, 46 Pac. at 87. See also, In re Portnoy, 21 Cal. 2d 237, 131 P.2d 1 (1942); People v. Smith, 161 Cal. App. 2d 860, 327 P.2d 636 (1958).

119 McQuILIIN, Municipal Corporations $\$ 26.01$ (3d ed. 1950).

12 John Rapp \& Son v. Kiel, 159 Cal. 702, 115 Pac. 651 (1911).

139 McQUinIn, Municipal Corporations $\$ 26.18$ (3d ed. 1950). 
granted.14 There may also be other requirements, such as the applicant's meeting the qualifications prescribed for the particular trade or profession. The dual character of the business license-regulation of busmess and raising of revenue-has caused great confusion whenever an inquiry has been made into the nature of a given license. Often the issue has been oversimplified. Thus, it is said that if the sole purpose of the fee is to raise revenue for general and unspecified governmental uses, the enactment stems from the taxing power of the issuing body.$^{15}$ Conversely, a hicense is said to be an exercise of police power when it is used to control the conduct and operation of a business and the fees are related to the expenses of administering the program. ${ }^{16}$ Under this approach it is assumed that there has been no regulation of business even though a city restricts business oportunities by requiring the payment of a fee as a condition precedent to obtaining a license, provided that the fee is intended solely to raise revenue.

In California, the state may grant licenses under its sovereign taxing and police powers, but a municipality has no inherent right to license and it must look to the state for authority. ${ }^{17}$ Both chartered and general law cities are authorized by article XI, section 11 of the constitution to enact regulatory ordinances that are not in conflict with general laws. ${ }^{18}$ The courts liave interpreted section 6 of article XI to permit charter cities to license for revenue as a legitimate exercise of home rule freedom. ${ }^{19}$ The state legislature, altlough it nuay withhold the power to license for revenue from general law cities, ${ }^{20}$ has authorized them to so license, ${ }^{21}$ but has expressly restricted the exercise of this power by making it subject to and controlled by the general laws. ${ }^{22}$ Thus, general laws control the revenue and regulatory ordmances of general law cities, as well as the regulatory measures of charter cities.

14 Id. at $\$ 26.01$.

15 Ibid.

16 RHXne, MunictPax LaW § 27-3 (1957) ; 9 MCQuIIIIN, MunictPat Corporations § 26.15 (3d ed. 1950).

17 "Whatever vested power the municipalities of the state enjoy they derive from the state Constitution and to the extent there permitted." City of San Mateo v. Railroad Comm'n, 9 Cal. 2d 1, 7, 68 P.2d 713, 716 (1937).

18 "Any county, city, town or township may make and enforce within its limits all such local, police, sanitary and other regulations as are not in conflict with general laws." Car. CoNST. art. XI, §11. The term "general laws" relates to all federal and California statutory provisions, as well as to the provisions of the United States Constitution.

The early interpretation was that "[S]ections 11 and 12 of article 11 intended to give full power and authority to the local governments over the subject of hicenses, whether for purposes of regulation or revenue, subject to be controlled by general laws." Ex parte Walter, 65 Cal. 269, 271, 3 Pac. 894, 895 (1884) (concurring opinion), cited with approval in Ex parte Mount, $66 \mathrm{Cal} .448,6 \mathrm{Pac}$. 78 (1885). Language to the sane effect may be found in In re Guerrero, $69 \mathrm{Cal} .88,91,10 \mathrm{Pac} .261,263$ (1886). But simce the turn of the century it has been settled that $\$ 11$ does not constitute a grant of authority to enact revenue measures. Peppin, Municipal Home Rule in California: III, 32 CALIF. L. REV. 341, 343 (1944).

10 E.g., Ex parte Braun, 141 Cal. 204, 74 Pac. 780 (1903).

20 See text at note 6 supra.

21 CAL. Gov'T CODE $\$ 37101$ provides: "The legislative body may license, for revenue and regulation, and fix the license tax upon, every kind of lawful business transacted in the city, including shows, exhibitions, and games ....."

22 CAL. Gov'T CODE $\$ 37100$ provides: "The legislative body may pass ordinances not in conflict with the Constitution and Laws of the State or the Umited States." Since regulatory powers are controlled by art. XI, $\S 11$, it would appear that this section was intended expressly to restrict the "inuncipal affairs" exception to charter cities and not to extend a similar freedom to general law cities. 


\section{III \\ HOW CONFLICTING LICENSES ARE RESOLVED}

Today, state regulation of businesses by various licensing acts reaches almost all business and professional activities carried on in California. ${ }^{23}$ When both the state and a city have licensed the same occupation, the courts have often been required to decide whether the inunicipal ordinance is invalid because of a conflict between the two licenses. Since the state hicensing acts generally contain no expression of the extent to which municipal hicensing is to be precluded, ${ }^{24}$ the issue faced by the courts is whether the legislature has inpliedly intended to occupy the field. By the mid-1940's it was settled that if both city and state granted a license and if the purpose of each hicense was to regulate business, a conflict existed and the city enactment was invalid. ${ }^{25}$ This was true whether a general law or charter city was involved.$^{26}$ However, if a licensing ordinance of a charter city was intended to raise revenue and the state license was regulatory, courts avoided finding a conflict ${ }^{27}$ by the facile method of labelling revenue raising activities "Inunicipal affairs."28

${ }^{23}$ Licensing regulations encompassing some thirty-two occupations may be found in the Business and Professions Code, Education Code, and Insurance Code. In 1957, additional licensing legislation was recommended for forty-nime occupations. Senate Interim Committec on Licensing Business and Professions, 1957 Report to the Legislature, Vol. 2, Appendix to the Journal of the Senate.

24 After the decisions by the supreme court in the two Agnew cases (see text at notes 42-47 infra), $\S 7032$, relating to licensing of contractors, was added to the Busimess and Professions Code. It reads: "Nothing in this chapter shall limit the power of a city ... to regulate the quality and character of installations made by contractors through a system of permits and inspections which are designed to secure compliance with and aid in the enforcement of applicable state and local building laws, or to enforce other local laws necessary for the protection of the public lealth and safety ....

"Nothing contained $m$ this section shall be construed as authorizing a city . . . to enact regulations relating to the qualifications necessary to engage in the busimess of contracting." Similar language revealing legislative intent is not found im other licensing acts.

25 E.g., John Rapp \& Son v. Kiel, 159 Cal. 702, 115 Pac. 651 (1911) (regulation of retail sale of liquor); Collins v. Priest, 95 Cal. App. 2d 179, 212 P.2d 269 (1949) (plumber); City \& County of San Francisco v. Boss, 83 Cal. App. 2d 445, 189 P.2d 32 (1948) (painting contractor); Horwith v. City of Fresno, 74 Cal. App. 2d 443, 168 P.2d 767 (1946) (electrical contractor); Hill v. City of Eureka, 35 Cal. App. 2d 154, 94 P.2d 1025 (1939) (attorney).

26 Art. XI, §11, sutpra note 18, applies to all cities; in addition, Gov'T CODE \$ 37100, supra note 22 , and $\$ 37101$, supra note 21 , control general law cities.

27 Ainsworth v. Bryant, 34 Cal. 2d 465, 211 P.2d 564 (1949); In re Galusha, 184 Cal. 697, 195 Pac. 406 (1921); Ex parte Braun, 141 Cal. 204, 74 Pac. 780 (1903); Security Truck Line v. City of Monterey, 117 Cal. App. 2d 441, 256 P.2d 366 (1953); Franklin v. Peterson, 87 Cal. App.2d 727, 197 P.2d 788 (1948); Redwood Theatres v. City of Modesto, 86 Cal. App. 2d 907, 196 P.2d 119 (1948); Trebilcox v. City of Sacramento, 91 Cal. App. 257, 266 Pac. 1015 (1928); In re Johnson, 47 Cal. App. 465, 190 Pac. 852 (1920).

28 In the case of $I n$ re Groves, 54 A.C. 146, 4 Cal. Rptr. 844, 351 P.2d 1028 (1960), it was decided that there was no conflict between a general law city revenue ordinance and a state regulatory statute. Ex parte Jackson, $143 \mathrm{Cal} .564,77 \mathrm{Cal} .457$ (1904) and City of Redding v. Dozier, 56 Cal. App. 590, 206 Pac. 465 (1922), botb dealt with general law city revenue licenses where the state had regulated the occupation, but in neither was the possibility of a conflict raised.

It is unsettled whether there is a conflict when the state licenses for revenue and the city, whether general law or charter, intends only to regulate.

Another possible area of conflict occurs when both a general law city and the state license for revenue. A general law city is empowered to license for revenue by Gov'T CODE $§ 37101$, supra note 21 , but when a general law city revenue measure conflicts with tlie general laws 
Horwith v. City of Fresno, ${ }^{29}$ decided in 1946, was the first of five district court of appeal decisions ${ }^{30}$ marking a change in judicial approach which would culminate twelve years later in the two supreme court Agneze ${ }^{31}$ opinions. The factual situations involved in all of these cases were similar - in each a charter city attempted to hicense a state licensed contractor. As this line of cases progressed, the courts showed less and less concern with the question whether the city license was a regulatory or revenue raising measure, seemingly invalidating city licensing per se because it conflicted with the state licensing scheme.

In the Horwith case, ${ }^{32}$ Fresno required license applicants, in this instance an electrical contractor, to pay a fee and to submit to an examination by a local board for a determination of competency. It was held that the ordinance was an unconstitutional regulation because the state had already occupied the field. In the course of its opinion the court made a significant statement which was to have great effect upon later cases: "The state license iniplies permission to the licensee to conduct his business at any place within the state. This permission should not be circumscribed by local authorities." ${ }^{33}$ In the next case, City $\&$ County of San Francisco v. Boss, ${ }^{34}$ the regulatory aspects of the city ordinance were less, but there was still held to be a conflict. The ordinance provided that a permit would be granted only if the applicant registered with the city as a state bicensed contractor, paid a $\$ 10$ fee, and a local bureau approved the application. If any facts in the application were found to be untrue, or if there was a showing that any rules or regulations had been violated, the permit could be denied. The court, noting that the fee was "not exacted solely for revenue," 35 relied upon Horverth to invalidate the ordinance. ${ }^{36}$ In Agnere v. City of Los Angeles, ${ }^{37}$ the prospective hicensee was required to submit to a brief examination, register with the city, post a surety bond, and pay a $\$ 100$ fee. Although these licensing requirenents were only minimal, the district court of appeal held the license to be regulatory and thus invalid because the legislature had intended that "licensing and regulation of contractors by the state shall be the only licensing and regulation in the

it may be invalid under $\S 37100$, supra note 22 . It is possible that a mere duplication of a state revenue license by a general law city license may result in the type of clash which $\$ 37100$ was meant to cover. It seems unlikely, lowever, that the state will lrave intended to occupy a revenue field to the exclusion of city enactments without a clear expression of legislative intent to that effect. A fair conclusion is that duplication of a state revenue license does not result in the invalidity of a general law city license.

2974 Cal. App. 2d 443, 168 P.2d 767 (1946).

30 The other four: Agnew v. City of Culver City, 147 Cal. App. 2d 144, 304 P.2d 788 (1956); Lynch v. City of Los Angeles, 114 Cal. App. 2d 115, 249 P.2d 856 (1952); Agnew v. City of Los Angeles, 110 Cal. App. 2d 612, 243 P.2d 73 (1952); City \& County of San Francisco v. Boss, 83 Cal. App. 2d 445, 189 P.2d 32 (1948).

31 Agnew v. City of Culver City, 51 Cal. 2d 474, 334 P.2d 571 (1959); Agnew v. City of Los Angeles, 51 Cal. 2d 1, 330 P.2d 385 (1958).

32 Horwith v. City of Fresno, 74 Cal. App. 2d 443, 168 P.2d 767 (1946).

33 Id. at $448-49,168 \mathrm{P} .2 \mathrm{~d}$ at 770.

3483 Cal. App. 2d 445, 189 P.2d 32 (1948).

$35 I d$. at $451,189 \mathrm{P} .2 \mathrm{~d}$ at 35 .

38 "In spite of the state law which authorizes a contractor lrolding a state license to contract anywhere in the state, this ordinance limits his right to contract in San Francisco [by requiring a permit] ... which shall only be given him if the facts set forth in his application are found to be true by the city authorities." Ibid.

37 110 Cal. App. 2d 612, 243 P.2d 73 (1952). 
state."38 The district court of appeal reached the same result on similar facts in Lynch v. City of Los Angeles. ${ }^{39}$

Because of confusing language in the Boss, Agnew, and Lynch cases, it was not certain whether the ordinances were being struck down because they imposed additional regulations in an area already occupied by the state or because the field of hicensimg was itself fully occupied, regardless of whether the city license was one for revenue or regulation. When the problem subsequently reached the supreme court in the two Agnew $w^{40}$ cases, it seemed that the latter approach was adopted. In Agnew v. City of Los Angeles, ${ }^{41}$ a licensee was required to pay a fee based upon the gross receipts of his business and to register with the city prior to obtaining a permit. A local board could review the application and had the power to deny the license. The supreme court held the licensing ordinance invalid, stating that while a city could impose a tax upon businesses, it could not impose a tax in the forn of a license when the state had already licensed the same activity. ${ }^{42}$ As was pointed out by Justice Shenk in his dissent, the majority opinion seemed to invalidate a charter city licensing ordinance enacted solely to raise revenue. ${ }^{43}$ The second supreme court case, Agnew v. City of Culver City ${ }^{44}$ held that a city could not enforce a municipal bicense with criminal penalties when the state had already granted a license, even though the licensing ordinance seemed to be intended only to raise revenue. ${ }^{45}$ It appeared that the court looked with disfavor upon any city measure, criminal or civil, which could be used to deny permission to do business when the applicant already possessed a state license.

As a result of the supreme court decisions in the two Agnew cases it seemed clear that a city could not require a hicense of any type from a state licensed businessman, and that the permission granted by the state to do business any-

38 Id. at 616,243 P.2d at 75 .

39114 Cal. App. 2d 115, 249 P.2d 856 (1952). There seemed to be confusion in these two cases as to the nature of the license fee. The city argued that it was merely a reasonable cliarge to cover inspection expenses and was a legitimate exercise of the police power. The court did not agree that the fee was reasonable and stated that the city did not imtend to use the funds to defray regulation expenses. If the funds were used only for revenue purposes, it would appear that this was merely a revenue measure by a charter city, i.e., a "municipal affair." Apparently this point was never raised or there were otber regulatory aspects sufficient to constitute a conflict without regard to the nature of the fee.

40 Agnew v. City of Culver City, 51 Cal.2d 474, 334 P.2d 571 (1959); Agnew v. City of Los Angeles, 51 Cal. 2d 1, 330 P.2d 385 (1958).

4151 Cal. 2d 1, 330 P.2d 385 (1958).

42 "Of course ... a municipality may" tax electrical contractors as other trades, professions and businesses are taxed. The fees in the present case, lowever, are exacted not as a business tax but as the price of a license that the city cannot require." Id. at 7, 330 P.2d at 388 (enpluasis added).

43 Agnew v. City of Los Angeles, 51 Cal. 2d 1, 9, 330 P.2d 385, 389 (1958). Justice Shenk based his argument upon what appeared to be the revenue raising purpose of the ordinance. He argued that it was a valid enactment in the area of "muncipal affairs."

4451 Cal. 2d 474, 334 P.2d 571 (1959).

45 In a prior appeal of this case a district court of appeal invalidated two separate ordinance provisions because of conflicts with the state licensing scheme. Agnew v. City of Culver City, 147 Cal. App. 2d 144, 304 P.2d 788 (1956). The first provision required applicants to pay a $\$ 100$ fee to the city prior to the issuance of a license and was enforced by a misdemeanor penalty. The second provision directed applicants, after procuring a license, to undergo an examination as to their qualifications. The district court of appeal reunanded the case to the trial court and after further findings there the city brouglit the present appeal to the supreme court to test the validity only of the first ordinance provision. 
where within the state could not be circumvented by a local measure. ${ }^{46}$ However, in a 1960 decision, In re Groves, ${ }^{47}$ the supreme court retreated toward the pre-1946 view ${ }^{48}$ that a conflict occurred only when city and state licensing measures were both regulatory. In Groves, Palm Springs, a general law city, required busimessmen to secure a permit and to pay a $\$ 100$ fee in order to do business within the city. Petitioner, a state licensed manufacturer of dairy products, refused to obtain the permit and was convicted of a misdemeanor for violating the local ordinance. He argued that lis state license gave him permission to do business in Palm Springs and that the city could not negate that permission by requiring an additional license. The court, speaking through Justice Traynor, rejected the petitioner's argument and sustained the conviction, holding that the city license was intended only to raise revenue and, as such, it was a valid business tax even though enforced by a license and by criminal penalties. ${ }^{49}$ The two supreme court Agnew cases were distinguished on the ground that the municipal licenses there were intended to regulate, not to tax. ${ }^{50}$ To reach the conclusion that there was no conflict between the state and municipal licenses, ${ }^{51}$ the court lield that a general law city revenue license does not conflict with a state regulatory license. Cited as authority for this proposition were cases involving charter cities where the possibility of conflict was often not even in issue because of the "municipal affairs" exception. ${ }^{52}$ The court's reliance upon these cases may perhaps be interpreted to mean that they do not stand for the proposition that a revenue license is a "municipal affair" in the sense that there is freedom from legislative interference, ${ }^{53}$ but that where there is a revenue ordinance there is not sufficient regulation of the licensee to amount to a conflict with the state. ${ }^{54}$ The court did not indicate how much more regulation would be necessary before a city license would conflict with a state hicensing act. ${ }^{55}$

46 See Note, 47 CaITf. L. Rev. 607 (1959) ; Note, 11 Stan. L. Rev. 782 (1959); Comment, 7 U.C.I.A.L. REv. 102, 114 (1960).

4754 A.C. 146, 4 Cal. Rptr. 844, 351 P.2d 1028 (1960).

48 See text at notes $24-28$ supra.

48 "Whether or not state law has occupied the field of regulation, cities may tax busmesses carried on within their boundaries and enforce such taxes by requiring business licenses for revenue and by criminal penalties." 54 A.C. at 149, 4 Cal. Rptr. at 846, 351 P.2d at 1030.

50 "In the Agnew cases the license fees were not imposed solely for revenue purposes but as an inseparable part of a regulatory scheme excluded by state law .... In the present case, however, the city seeks to enforce its licensing ordinance against petitioner for revenue only, and as the Agnew cases expressly recognized, such taxation is not excluded because the state has occupied the field of regulation." Id. at 150, 4 Cal. Rptr. at 847, 351 P.2d at 1031.

51 See note 28 supra for cases factually similar, but where the conflict question was not raised.

52 In re Galusha, 184 Cal. 697, 195 Pac. 406 (1921) (Los Angeles); Franklin v. Peterson, 87 Cal. App. 2d 727, 197 P.2d 788 (1948) (Los Angeles); City of San Mateo v. Mullin, 59 Cal. App. 2d 652, 139 P.2d 351 (1943); In re Johnson, 47 Cal. App. 465, 196 Pac. 852 (1920) (Marysville).

53 Ex parte Braun, 141 Cal. 204, 74 Pac. 780 (1903), is apparently contra.

54 This position is supported by In re Galusha, 184 Cal. 697, 195 Pac. 406 (1921).

55 To sustain petitioner's conviction, the court also had to hurdle a Palm Springs ordinance which expressly stated that the city criminal penalties did not apply to state licensees. The court reasoned that since it had been held in this state that a city ordinance is a state law (see Teachout v. Bogy, 175 Cal. 481, 166 Pac. 319 (1917)), the conviction could stand under Bus. \& Prof. CODE $\$ 16240$, which inakes carrying on a business without a license "required by any law of this State" a misdemeanor. By means of this rather surprising reasoning the petitioner was held to have heen properly convicted under the city ordinance. The holding would seem to introduce a new wrinkle into Califorria hicensing law-lienceforth, a city may enforce its revenue hicensing ordinances by criminal penalties, but it is the state's criminal penalties which must be used. Cf. note 10 supra. 
The Groves case was followed in a recent district court of appeal decision ${ }^{\text {to }}$ where a revenue license imposed by the city of Berkeley was sustained, even though it was applied to a state licensed contractor and was enforced by criminal penalties. The court distinguished the Agnew cases on the ground that there the license fees were a part of a regulatory scheme and not imposed solely for revenue.

\section{IV}

\section{IMPLICATIONS OF CITY AND STATE LICENSING}

The supreme court in the two Agnew ${ }^{57}$ cases and the Groves ${ }^{58}$ decision apparently took divergent views as to the effect of state hicensing. The view in Agnere is that the legislature has intended to occupy the field of licensing to the exclusion of local licensing enactments. Groves, on the other hand, stands for the proposition that the legislature has entered, but not occupied, the field of business regulation through hicensing, and that cities are not precluded from enacting licensing ordinances solely for the acquisition of revenue, even though they include a minimal amount of regulation. It is submitted that both of these views result in mechanical solutions without regard to the realities of the problem. In addition to deciding whether cities or the state should have the ultimate control over business licensing, other complex issues are involved relating to the cities' needs for revenue, the detrimental economic effects on intercity or intrastate commerce, and the right to do business in local markets.

Cities depend upon licensing as a source of revenue..$^{50}$ There is nothing wrong with allowing cities to tax businesses-after all, they should bear their proportionate share of the cost of government services. ${ }^{60}$ Although the business hicense is an effective tool to insure compliance with taxing measures, it may be questioned whether the advantages to be gained from such a method of taxation are not outweighed by the burden which may be imposed upon the commerce of the state. Unquestionably, under the present system in which almost all cities impose flat hicense fees, individuals who engage in occupations which depend upon market areas extending beyond municipal boundaries bear greater burdens than those who carry on a business within a single city. Take, for instance, two individuals in a similar occupation; one does the same amount of business with seven stores in a large city as the other does with seven stores in seven smaller suburban communities. If taxed upon the amount of business done, both would pay approximately the same amount in taxes. But if the tax is imposed through the use of a flat license fee, one individual nay have to pay seven times more than the other. Of course, the restrictive effect of city licensing would exist whether or not the state has hicensed. When the state has licensed, the question is whether the legislature has intended to relieve businessmen of oppressive local licensing or whether it recognizes the problems involved, but feels that city licensing should be permissive.

In Groves and the two Agnew cases, the supreme court was faced with the same

56 Arnke v. City of Berkeley, 185 A.C.A. 931, 8 Cal. Rptr. 645 (1960).

${ }^{57}$ Agnew v. City of Culver City, 51 Cal. 2d 474, 334 P.2d 571 (1959); Agnew v. City of Los Angeles, 51 Cal.2d 1, 330 P.2d 385 (1958).

58 In re Groves, 54 A.C. 146, 4 Cal. Rptr. 844, 351 P.2d 1028 (1960).

59 Excluding figures from San Francisco and Los Angeles, business licensing accounted for $4.3 \%$ of all mumicipal revenue in the two-year 1954-1955 period. Davisson, Business License TAXEs 1 (1957) (published by the League of California Cities).

60 Both Agnew v. City of Los Angeles, 51 Cal.2d 1, 330 P.2d 385 (1958) and the Groves case agreed that a city could tax a business; they disagreed as to the method of taxation. 
problem-that of speculating as to legislative intent. The Agnew cases apparently favored the restriction of city licensing authority because of possible burdensome economic effects, regardless of the resulting loss of revenue to the cities. Groves, on the other hand, seemingly endorsed a policy of allowing cities freely to raise revenue through the use of licenses even thougli they may inflict multiple burdens upon intercity commerce. In view of the statewide matters involved, it may be asked whether it is not more desirable to leave the final resolution of the problem to the legislature.

In spite of the Groves case, the better position would seem to be that municipal licensing powers should be restricted. ${ }^{81}$ The use of a flat rate tax disguised as a license fee discriminates against intercity businesses and is inconsistent with the goal of free movement in intrastate commerce. ${ }^{62}$ To assure cities of a continued source of revenue from licensing while removing the oppressive effects of the present day system, a two-pronged program may be suggested. The legislature should restrict the licensing authority of general law cities by allowing only those fees which are reasonably related to the amount of business done within the city. ${ }^{63}$ Such a statute would be of no effect as to the "municipal affairs" freedom of charter cities, but the courts, in response to legislative action, could recognize that in reality revenue hicenses are no longer "municipal affairs."

Today, licensing, whether used to regulate or to acquire revenue, is of statewide concern since its impact reaches beyond city boundaries. When it is understood that revenue licensing by either a general law or charter city should be controlled-as regulatory licensing is now controlled-by general laws of the state defining the scope of municipal powers, the present unrealistic and oppressive system will give way to a program beneficial to the businesses of the state as a whole.

Rondell B. Hanson

61 In the past, some courts have voiced disapproval of restrictive licensing by municipalities. "The general policy of the state is opposed to the raising of revenue by the collection of direct taxes as a condition precedent to the conduct of business." In re Gritton, 46 Cal. 2d 856, 858, 300 P.2d 7, 8 (1956). See also Hill v. City of Eureka, 35 Cal. App. 2d 154, 158, 94 P.2d 1025,1027 (1939). "This public policy argument, while it does not result in a loolding of lack of power to tax, does suggest that such tax ordinances inust be scrutinized carefully ...." Security Truck Line v. City of Monterey, 117 Cal. App. 2d 441, 453, 256 P.2d 366, 374 (1953). "[I]f the city of Redding may impose such a tax every other inunicipality in the state may impose a similar tax upon the same individual if he crosses its borders. ... Even though the tax imposed by one city miglit not be burdensome additional levies by others could readily become so." In re Porterfield, 28 Cal. 2d 91, 117, 168 P.2d 706, 722 (1946) (license fee imposed upon a union solicitor).

62 There seem to be no constitutional or legislative provisions in California concerning the regulation of intrastate commerce, but in the interest of the econony of the state it cannot be doubted that commercial regulation slould take place at the state level rather than allowing the cities to regulate on a pieceineal basis.

03 See Arnke v. City of Berkeley, 185 A.C.A. 931, 8 Cal. Rptr. 645 (1960), where the license fees were based upon the average number of people employed in the hicensed business during the period in which the business was conducted witlin the city. 